\title{
Proinflammatory Cytokine Expression in the Endolymphatic Sac During Inner Ear Inflammation
}

\author{
Hitoshi Satoh, ${ }^{1,3}$ Gary S. Firestein, ${ }^{2}$ Peter B. Billings, ${ }^{1}$ Jefrerey P. Harris, ${ }^{1,3}$ \\ and Elizabeth M. Keithley, ${ }^{1,3}$ \\ ${ }^{1}$ Division of Otolaryngology-Head and Neck Surgery, University of California, San Diego, CA 92093, USA \\ ${ }^{2}$ Division of Rheumatology, Allergy and Immunology, University of California, San Diego, CA 92093, USA \\ ${ }^{3}$ Research Service, Department of Veterans Affairs, San Diego, CA, 92161, USA
}

Received: 5 June 2002; Accepted: 12 August 2002; Online publication: 5 November 2002

\section{ABSTRACT}

The inner ear is capable of rapidly mounting an immune response that can ultimately lead to cochlear degeneration and permanent hearing loss. The role of the endolymphatic sac in this immune process is not clear. In order to investigate the cytokine expression of cells within the endolymphatic sac, a secondary inner ear immune response to keyhole limpet hemocyanin $(\mathrm{KLH})$ was created in mice. The animals were sacrificed $3-48 \mathrm{~h}$ and 7 days following initiation of the immune response. The cochleas and endolymphatic sacs were assayed by immunocytochemistry for IL- $1 \beta$, TNF $\alpha$, and IL- 6 . Three hours after KLH challenge of the scala tympani, the perisaccular tissue of the endolymphatic sac contained more inflammatory cells than the scala tympani or endolymphatic sac lumen. Only a few of these cells, however, expressed the proinflammatory cytokines IL- $1 \beta$ and TNF $\alpha$ between 3 and $12 \mathrm{~h}$ after KLH injection. On the other hand, TNF $\alpha$, which plays an important role in the cochlear secondary immune response, was expressed in cells in the endolymphatic sac lumen. The maximum percentage of cells expressing $\mathrm{TNF} \alpha$ was seen later than in the scala tympani. Animals treated with systemic injection of the TNF blocker, etanercept, showed a reduction in the number of cells in the endolymphatic sac lumen. It is concluded that the cells in the endolymphatic sac

Correspondence to: Elizabeth M. Keithley - Division of Otolaryngology-Head and Neck Surgery 9500 Gilman Drive - University of California, San Diego • La Jolla, CA 92093-0666. Telephone: (858) 534-2201; fax: (858) 534-5319; email: ekeithley@ucsd.edu lumen contribute to the amplification of the adaptive immune response by expressing $\mathrm{TNF} \alpha$, while the infiltration of cells into the perisaccular connective tissue is part of the nonspecific, innate, cochlear immune response.

Keywords: inner ear immunity cochlear inflammation, innate immunity

\section{INTRODUCTION}

The inner ear is an organ capable of rapidly generating an active immune response (Harris 1984), although, like the brain, it has a blood-labyrinthine barrier (Juhn 1981) and few resident macrophages (Takahashi and Harris 1988a; Satoh 1997). Because of these features it has been considered an immunologically privileged organ, although it does have connections to the lymphatic system via cervical lymph nodes (Yimtae et al. 2001). Hearing loss in some individuals is thought to be mediated by inner ear immune responses (McCabe 1979), and treatment with immunosuppressive drugs can restore cochlear function in some patients (Kanzaki and Ouchi 1981).

An animal model of immune-mediated labyrinthitis induced by immunization with keyhole limpet hemocyanin (KLH) has been developed to study the cellular and physiological events related to initiation and amplification of inner ear adaptive immune responses (Takahashi and Harris 1988b; Chen et al. 1998; Tomiyama and Harris 1986; Harris 1984; Ma et al. 2000). The site of antigen processing and 
presentation for the inner ear is generally thought to be the endolymphatic sac (Rask-Andersen and Stahle 1979, 1980; Rask-Andersen et al. 1983). Surgical destruction of the endolymphatic sac or isolation of the sac from the cochlea by destruction of the duct greatly reduces the cochlear inflammation normally seen after cochlear KLH challenge (Tomiyama and Harris 1986, 1987). Thus, there is no doubt that the endolymphatic sac is critically involved in the cochlear immune response.

We have shown that the cytokine $\mathrm{TNF} \alpha$ plays a key role in immune-mediated cochlear injury since etanercept, a blocker of $\mathrm{TNF} \alpha$ activity, significantly attenuates local inflammation after immunization as assessed both histologically (Satoh et al. 2002) and functionally (Wang et al. 2002). In this article, we investigate the expression of proinflammatory cytokines within the endolymphatic sac lumen and the surrounding connective tissue during the early stages of labyrinthitis. Based on the cytokine expression pattern, we postulate that the inflammatory cells of the surrounding connective tissue are related to the innate cochlear immune response and the cells within the lumen contribute to the initiation of the adaptive immune response.

\section{MATERIALS AND METHODS}

\section{Animals}

Female albino National Institutes of Health Swiss mice (Harlan Sprague Dawley, Inc., Indianapolis, IN), weighing from 20 to $24 \mathrm{~g}$, were used. Prior to surgery and sacrifice, each mouse was deeply anesthetized with a mixture of ketamine hydrochloride $(50 \mathrm{mg} / \mathrm{kg})$, xylazine hydrochloride $(5 \mathrm{mg} / \mathrm{kg})$, and acepromazine maleate $(1 \mathrm{mg} / \mathrm{kg})$ intramuscularly. All the animal work was done in accordance with the animal use committee of the Veterans Affairs Medical Center.

\section{Antigen preparation}

The KLH (Pacific Biomarine Laboratories, Port Hueneme, CA) was an ammonium sulfate precipitate and prepared for use as follows: The slurry was suspended in phosphate-buffered saline (PBS), pH 6.4, dialyzed aseptically against $\mathrm{PBS}$, and then centrifuged for $20 \mathrm{~min}$ at $20,000 \mathrm{~g}$. The supernatant was recentrifuged for $90 \mathrm{~min}$ at $87,000 \mathrm{~g}$. The pellet (associated $\mathrm{KLH}$ ) was dissolved in PBS for systemic sensitization and intracochlear injection.

\section{Secondary inner ear immune response}

An inner ear immune response was generated by directly challenging the inner ear with KLH. Animals were first systemically sensitized to KLH by subcutaneous injection of the antigen in the back $(0.2 \mathrm{mg}$ KLH emulsified in Freund's complete adjuvant). Two weeks later they were boosted $(0.2 \mathrm{mg} \mathrm{KLH}$ in Freund's incomplete adjuvant). Ten days later the right cochlea was injected with KLH $(0.1 \mathrm{mg}$ in $5 \mu \mathrm{l}$ PBS, $\mathrm{pH}$ 6.4) through a microhole drilled through the cochlear capsule. The left cochlea served as a normal, nonsurgical control. The right cochlea was approached using an operating microscope and sterile technique. A postauricular incision was made and a hole was drilled into the bulla to allow good visualization of the promontory of the cochlear basal turn, stapedial artery, and round window niche. The stapedial artery was cauterized and removed and a hole $(25 \mu \mathrm{m})$ was drilled through the cochlear capsule into the scala tympani of the lateral basal turn. The overflow of perilymph was gently removed by suction. KLH was very slowly injected using pressure from an air-filled Hamilton syringe coupled with plastic tubing to a glass micropipette containing the antigen. The hole was sealed with bone wax after injection and any excess fluid was removed. Five mice were sacrificed at each of the following time points after KLH injection: 3, 6, 24, 48, and $168 \mathrm{~h}$ (7 days). Seven mice were sacrificed after $12 \mathrm{~h}$.

To determine the effects of surgery and fluid injection into the cochlea on cytokine expression, 5 mice were sacrificed 3 and $12 \mathrm{~h}$ after injection of sterile PBS $(5 \mu \mathrm{l})$ into the cochlea. Two mice were sacrificed after 24 and $168 \mathrm{~h}$.

\section{Blockage of TNFa}

Fourteen KLH-sensitized mice were divided randomly into one of two groups of 7 animals each. Etanercept, Enbrel $^{\mathrm{TM}}$ (recombinant human TNF receptor: human $\operatorname{IgG}_{1}$ Fc fusion protein, rhuTNFR:Fc; Immunex, Seattle, WA) (2.5 mg in $0.1 \mathrm{ml}$ ), purchased through a pharmacy, was intraperitoneally (IP) injected into one group of 7 mice 10 min before KLH injection into the cochlea. Three days after the first etanercept injection, the same dose of etanercept was injected again. The other 7 mice did not receive the drug treatment, only intracochlear KLH. All the animals were sacrificed 7 days after cochlear KLH injection. The number of inflammatory cells in the cochlea and endolymphatic sac and IL-6 expression in these cells was compared between the two groups.

\section{Tissue preparation and immunohistochemistry}

At the designated survival time the animals were deeply anesthetized as described above and sacrificed by intracardiac perfusion of heparinized warm saline, followed by about $40 \mathrm{ml}$ of periodate-lysine-parafor- 
maldehyde (4\% paraformaldehyde final concentration) fixative. The temporal bones were immediately removed and decalcified with buffered 5\% ethylenediaminetetraacetate (EDTA) ( $\mathrm{pH} 7.2)$ for 14 days $\left(4^{\circ} \mathrm{C}\right)$. After decalcification, temporal bones were immersed sequentially in increasing concentrations $(50 \%, 75 \%, 100 \%)$ of Optimal Cutting Temperature (O.C.T.) compound (Tissue-Tek; Miles Inc., Elkhart, IN), snap-frozen $\left(-70^{\circ} \mathrm{C}\right)$, and cryostat-sectioned (4 $\mu \mathrm{m})$ parallel to the modiolus. Sections were collected for hematoxylin and eosin (H \& E) staining and immunohistochemistry.

IL-1 $\beta$, IL-6, and TNF $\alpha$ expression was investigated using affinity-purified goat anti-mouse IL-1 $\beta(25 \mu \mathrm{g} /$ $\mathrm{ml})$, IL-6 $(25 \mu \mathrm{g} / \mathrm{ml})$, and TNF $\alpha(6.25 \mu \mathrm{g} / \mathrm{ml})$ polyclonal antibodies (R\&D Systems, Minneapolis, MN) in PBS with $0.1 \% \mathrm{BSA}$ and $0.1 \% \mathrm{NaN}_{3}$. The sections were incubated with $0.6 \% \mathrm{H}_{2} \mathrm{O}_{2}$ in methanol for 20 min at room temperature (RT) to inactivate endogenous peroxidases and then incubated with $9 \%$ normal rabbit serum with $0.1 \% \mathrm{NaN}_{3}$ for $60 \mathrm{~min}$ at $37^{\circ} \mathrm{C}$ to inhibit nonspecific binding of secondary antibody. Sections were incubated at RT for $1 \mathrm{~h}$ with primary antibody. Control sections were incubated with normal goat IgG (Sigma, St. Louis, MO). Following incubation the sections were washed with PBS for $30 \mathrm{~min}$. Biotinylated rabbit anti-goat IgG (Vector Laboratories, Burlingame, CA) was used for $30 \mathrm{~min}$ at RT as secondary antibody. Antibody binding was detected using an Elite ABC Kit (Vector) for $30 \mathrm{~min}$ at RT with $3,3^{\prime}$-diaminobenzidine- $\mathrm{H}_{2} \mathrm{O}_{2}$ as chromagen. The specimens were dehydrated in graded ethanol and immersed in Citrisolv (Fisher Scientific, Tustin, CA) before mounting in Permount (Fisher).

KLH distribution in the endolymphatic sac was evaluated immunohistochemically using guinea pig anti-KLH serum (1:2000) as the primary antibody and affinity-purified biotinylated goat anti-guinea pig IgG (Vector) as the secondary antibody. The same detection system was used as described above. Nonimmune guinea pig serum was used as a reagent control.

For the development of the immunohistochemical assays, we used lipopolysaccharide (LPS)-stimulated spleen as positive control tissue. Three mice were injected intraperitoneally with $800 \mu \mathrm{g} / \mathrm{kg}$ of LPS (Sigma) and sacrificed 2, 4, and $6 \mathrm{~h}$ after injection. Spleen tissue was processed through the same preparative steps as the cochlea. The antibodies for IL-1 $\beta$, $\mathrm{TNF} \alpha$, and IL-6 identified the cytokine-expressing cells among the cells of the red pulp.

\section{Data analysis}

For each primary antibody, randomly chosen cochlear sections (more than 10 in most cochleas) and sections containing the endolymphatic sac $(n=4$ / cochlea) were immunolabeled. For each antibody, the number of labeled cells was counted in each section and an average was calculated. The total number of inflammatory cells was also counted within the same sections using Nomarski differential interference contrast optics. Inflammatory cells were identified by their spherical shape as opposed to the spindle-shaped fibrocytes or cuboidal-shaped epithelial cells of the endolymphatic sac. The percentage of labeled inflammatory cells/section was then calculated. The cells in the cochlear scalae and those in the perisaccular connective tissue and endolymphatic sac lumen were evaluated separately. The adjacent section was sometimes stained with $\mathrm{H} \& \mathrm{E}$, if necessary, for an accurate assessment of the total number of inflammatory cells.

For the evaluation of the ability of etanercept to reduce inflammation, cochlear sections (usually more than 8) and sections containing the endolymphatic sac $(n=4)$ were randomly chosen and stained with $\mathrm{H} \& \mathrm{E}$, the number of inflammatory cells was counted in each section, and an average was calculated.

\section{RESULTS}

\section{KLH-induced inflammation}

The normal, left cochlea in the NIH Swiss mice used for this study contained few, if any, inflammatory cells. The perisaccular connective tissue contained about 6 inflammatory cells/section and the lumen contained 0-1 inflammatory cells/section. Mice that were systemically sensitized to KLH reacted quickly to $\mathrm{KLH}$ injected into the cochlea with infiltration of inflammatory cells from the systemic circulation. The number of inflammatory cells/section increased over the course of a week (Fig. 1). Inflammatory cells entered both the cochlea and the endolymphatic sac lumen and perisaccular connective tissue. Evaluation of the time course of this process indicated that more inflammatory cells were present in the perisaccular region of the endolymphatic sac than in the cochlea at 3,6 , and $12 \mathrm{~h}$ post-KLH injection into the cochlea. It was not until 12-24 h after KLH challenge of the cochlea that the number of cells/section infiltrating the cochlea was as great as the number in the perisaccular tissue. The number of cells present in the perisaccular region continued to increase until $48 \mathrm{~h}$ after KLH challenge, after which the number of cells stabilized for at least the next 5 days. This is in contrast to what happened in the cochlea where the number of inflammatory cells continued to increase between $6 \mathrm{~h}$ and 7 days.

The number of cells in the lumen of the endolymphatic sac was very small at all time points, but increased slowly over time. 


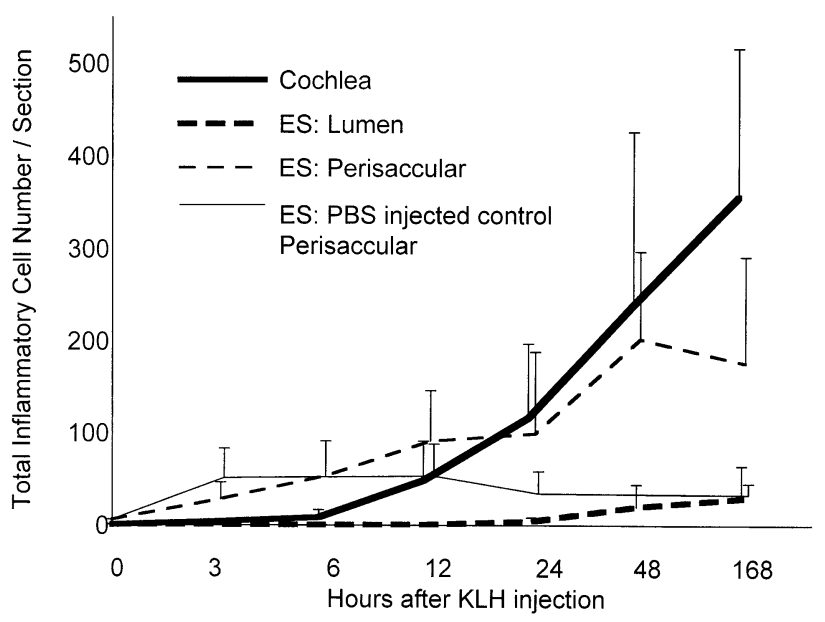

FIG. 1. Number of cochlear and endolymphatic sac inflammatory cells/section at specific time points following cochlear challenge with PBS or $\mathrm{KLH}$ in $\mathrm{KLH}$-sensitized animals. Mean and standard deviation at each time point are shown.

Injection of PBS into the cochlea also induced the infiltration of inflammatory cells into the perisaccular connective tissue of the endolymphatic sac. The number of inflammatory cells was the same at 3-12 h, as shown for KLH injection in the cochlea (Fig. 1). In contrast, the number of inflammatory cells in the cochlear scalae following PBS injection was minimal.

\section{KLH distribution after cochlear injection}

In order to identify the location of the injected antigen, KLH in the tissue sections was evaluated using immunohistochemistry. At $6 \mathrm{~h}$ after cochlear KLH injection, KLH was identified in the immunocompetent cells in the perisaccular region in 5 out of 5 cochleas (Fig. 2a). In one of these cochleas, KLHlabeled cells were also seen in the endolymphatic sac lumen. The number of KLH-positive cells in the lumen increased between 6 and $12 \mathrm{~h}$ so that 4 out of 6 cases had labeled cells in the endolymphatic sac lumen at this time (Fig. 2b). KLH-positive cells were still present in the perisaccular connective tissue at $12 \mathrm{~h}$. By $48 \mathrm{~h}$ after cochlear KLH injection, however, KLHpositive immunolabeled cells were no longer seen in the perisaccular region. Labeled cells were still seen in the endolymphatic sac lumen. The same was true after 7 days.

\section{Cytokine expression in the endolymphatic sac}

None of the epithelial cells that line the endolymphatic sac lumen or the fibroblasts of the perisaccular connective tissue expressed IL- $1 \beta$, TNF $\alpha$, or IL- 6 at any of the time points tested. After KLH challenge of the cochlea, the perisaccular connective tissue was quickly infiltrated with inflammatory cells (Fig. 1).

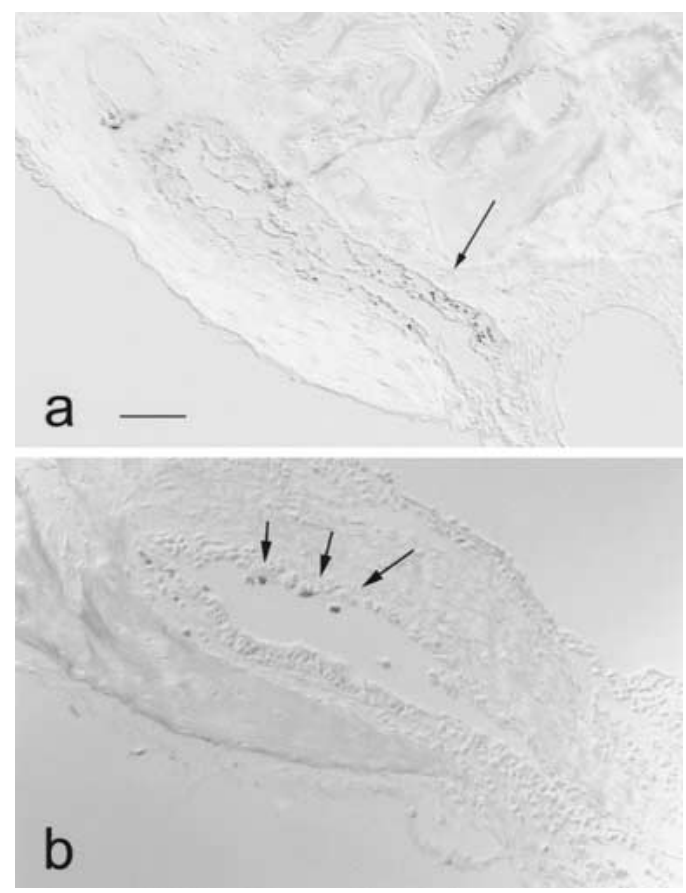

FIG. 2. a Photomicrograph (Nomarski optics) of KLH-immunolabeled cells in the perisaccular connective tissue $6 \mathrm{~h}$ after KLH cochlear injection (arrow). b Photomicrograph (Nomarski optics) of $\mathrm{KLH}$-immunolabeled cells in the lumen of the endolymphatic sac 24 $\mathrm{h}$ after KLH cochlear injection (arrows). Scale bar $=100 \mu \mathrm{m}$ for $\mathbf{a}$ and $\mathbf{b}$.

Only a few of these cells, however, expressed the proinflammatory cytokines IL-1 $\beta$, TNF $\alpha$, or IL-6 (Fig. 3A-C, Fig. 4a). The endolymphatic sac lumen, on the other hand, contained only a few inflammatory cells, but these cells did express the proinflammatory cytokines IL-1 $\beta$, TNF $\alpha$ (Fig. 4b), and IL-6 (Fig. 4c). With the methods that we used, it is not possible to determine whether the labeled cells were those present prior to KLH challenge of the cochlea or whether the labeled cells were among the cells that infiltrate the endolymphatic sac after KLH challenge.

The times at which the cytokine-positive cells were seen differed between the cochlea and the endolymphatic lumen. Labeled inflammatory cells were seen first in the cochlea, then in the endolymphatic sac lumen (Fig. 3A-C). Both IL-1 $\beta$ - and TNF $\alpha$-positive cells were present in the cochlea $3 \mathrm{~h}$ after cochlear KLH challenge. IL-1 $\beta$-expressing cells in the lumen, on the other hand, did not appear until $12 \mathrm{~h}$, and the greatest number was seen at $24 \mathrm{~h}$. Likewise, some TNF $\alpha$-positive cells were seen at 3 and $6 \mathrm{~h}$, but the greatest number was not seen until $12 \mathrm{~h}$ after cochlear KLH challenge. This is long after these cells were seen in the cochlea. As in the cochlea, where the number of TNF $\alpha$-expressing cells was greater than the number of IL-1 $\beta$-expressing cells, the number of TNF $\alpha$-expressing cells in the lumen at 12 hours was signifi- 

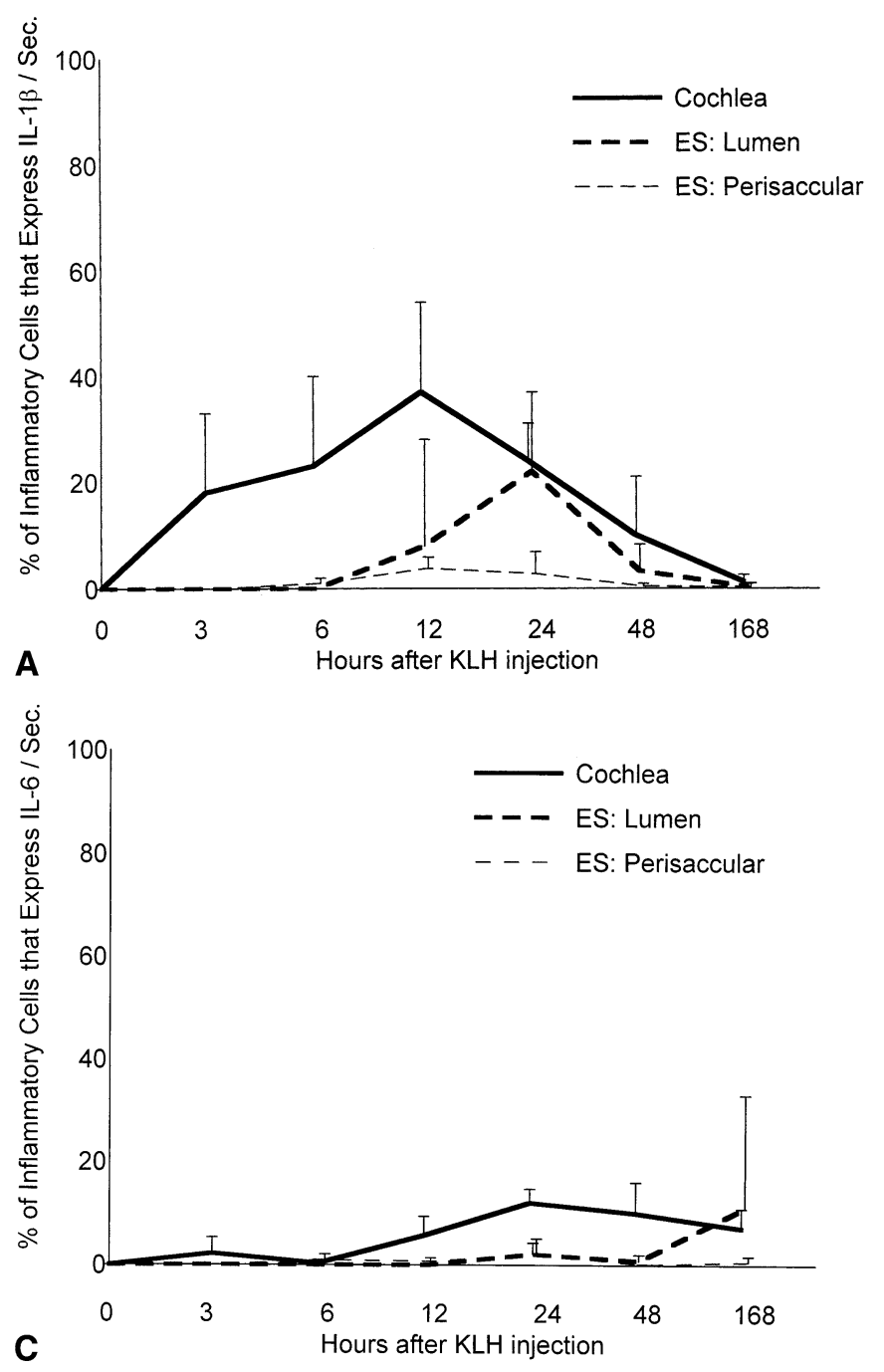

cantly greater than the number of IL-1 $\beta$ - or IL-6positive cells (ANOVA and Fisher's LSD, $p<0.05$ ).

Because of the very small number of cells within the endolymphatic sac lumen, the use of percentages in Figure 3 may be difficult to interpret, but it seemed the best way to normalize for the variations in absolute inflammatory cell number across animals. The difficulty arises when there are only a few cells. The high standard deviations in Figure 3 reflect this situation.

Although PBS injection into the cochlea induced inflammatory cell infiltration of the perisaccular connective tissue by $3 \mathrm{~h}$ after injection, no IL-1 $\beta$ - or IL-6-expressing cells were seen. TNF $\alpha$, on the other hand, was expressed in $1 \% \pm 1 \%$ of the perisaccular cells at $3 \mathrm{~h}$ following PBS injection into the cochlea. This number of positive cells was about the same as seen in an immune response.

\section{Suppression of inflammation by etanercept}

As reported previously, the number of inflammatory cells in the cochlea was significantly less at 7 days

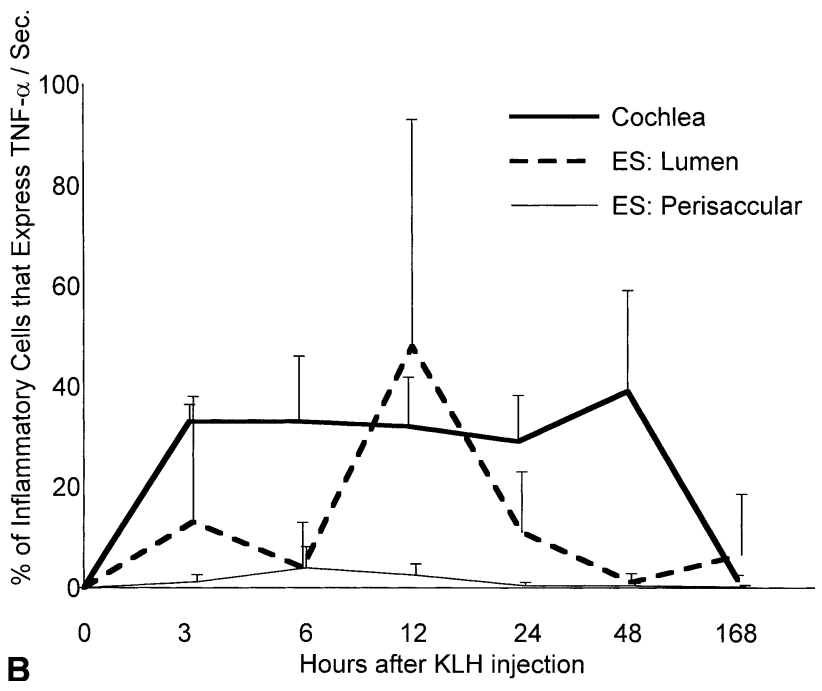

FIG. 3. Percentage of inflammatory cells that express (A) IL-1 $\beta$, (B) TNF $\alpha$, and (C) IL-6 in the cochlea and perisaccular and lumenal regions of the endolymphatic sac following $\mathrm{KLH}$ cochlear challenge. IL-1 $\beta$ expression in the endolymphatic sac followed expression in the cochlea. Very few cells expressed IL-6 in the endolymphatic sac lumen except after $168 \mathrm{~h}$ (7 days). TNF $\alpha$ expression in the perisaccular region peaked at $6 \mathrm{~h}$ and in the lumen at $12 \mathrm{~h}$ after cochlear $\mathrm{KLH}$ injection. This is later than the cochlear expression of this cytokine.

postchallenge in the animals treated with systemic etanercept (Satoh et al. 2002). The number of infiltrating cells in the endolymphatic sac lumen was also less in the group treated with etanercept at this time ( $p<0.05$, Mann-Whitney test) (Figs. 5, 6). It is most interesting however, that the number of inflammatory cells in the perisaccular connective tissue is not less in the animals treated with etanercept (Fig. 5).

\section{DISCUSSION}

The endolymphatic sac comprises a sac formed by epithelial cells surrounded by connective tissue containing blood vessels, the perisaccular connective tissue. Lymphatic vessels may also be present in this tissue (Rask-Andersen and Stahle 1980; RaskAndersen et al. 1983). The lumen is continuous with the endolymphatic compartment of the cochlea, and the perisaccular connective tissue is continuous with the perilymphatic compartment of the cochlea. 


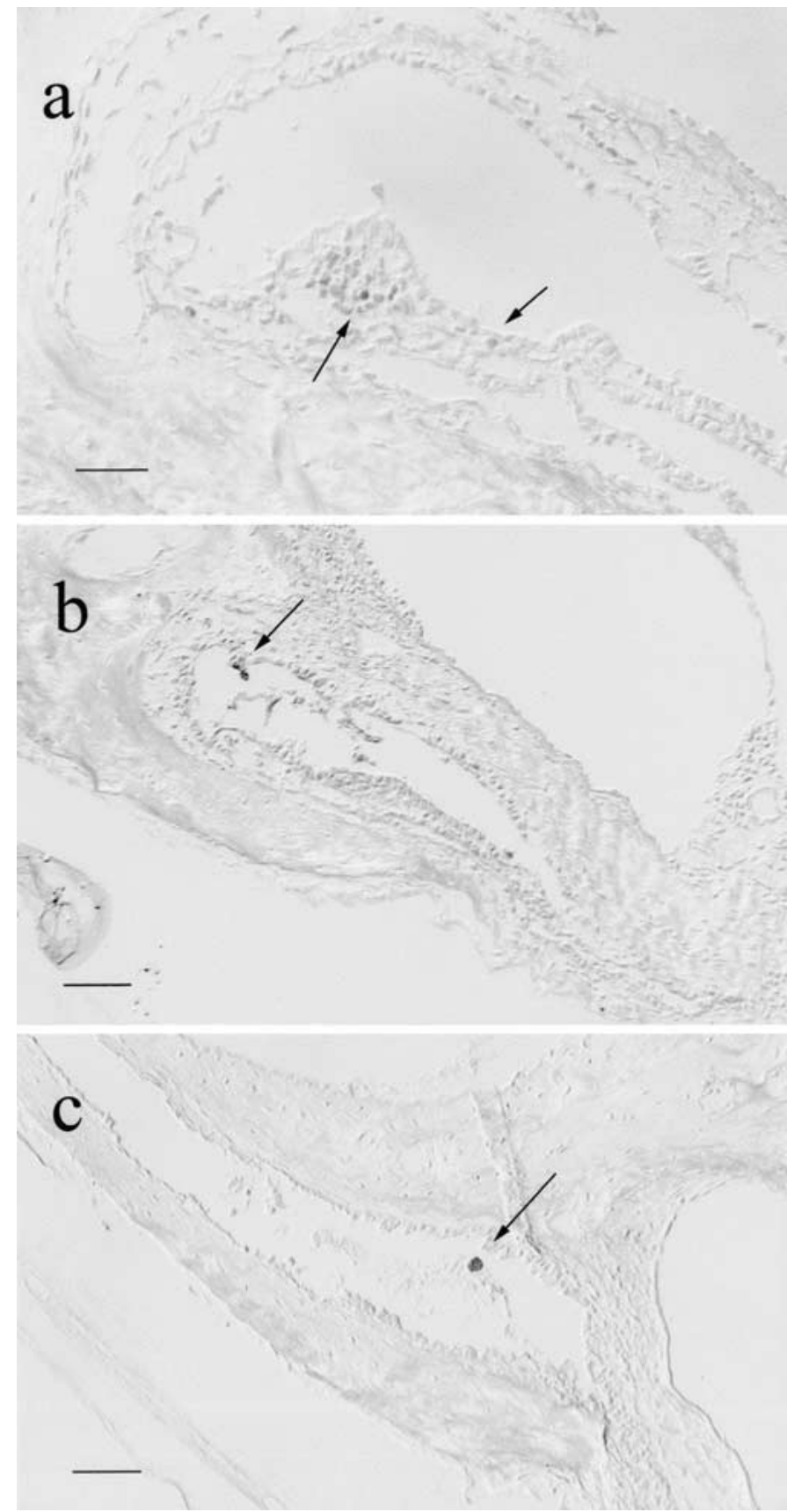

FIG. 4. Photomicrographs (Nomarski optics) of horizontal sections of the following: a KLH-inflamed mouse endolymphatic sac immunolabeled for IL-1 $\beta$ (arrows). The animal survived $12 \mathrm{~h}$ after the initiation of the inflammation; scale bar $=50 \mu \mathrm{m}$. b KLH-inflamed mouse endolymphatic sac immunolabeled for TNF $\alpha$ (arrows). The

The endolymphatic sac tissue, including the blood vessels, contributes to the generation of an inner ear immune response to a foreign protein. In nonsensitized animals, a foreign protein injected into the inner ear reaches the endolymphatic sac (Yeo et al. 1995) and the systemic immune system (Yimtae et al. 2001), and antibody against that protein is measurable in the serum after 2 weeks (Tomiyama and Harris animal survived $24 \mathrm{~h}$ after the initiation of the inflammation; scale bar $=100 \mu \mathrm{m}$. c KLH-inflamed mouse endolymphatic sac immunolabeled for IL-6 (arrows). The animal survived $24 \mathrm{~h}$ after the initiation of the inflammation; scale bar $=100 \mu \mathrm{m}$.

1986, 1987, 1989). In animals that are systemically sensitized to a foreign protein, subsequent injection of that protein into the cochlea results in labyrinthitis. Surgical destruction of the endolymphatic sac or duct results in a reduced ability to generate serum antibody in nonsensitized animals and a reduced cochlear inflammatory response in sensitized animals (Tomiyama and Harris 1986, 1987). 


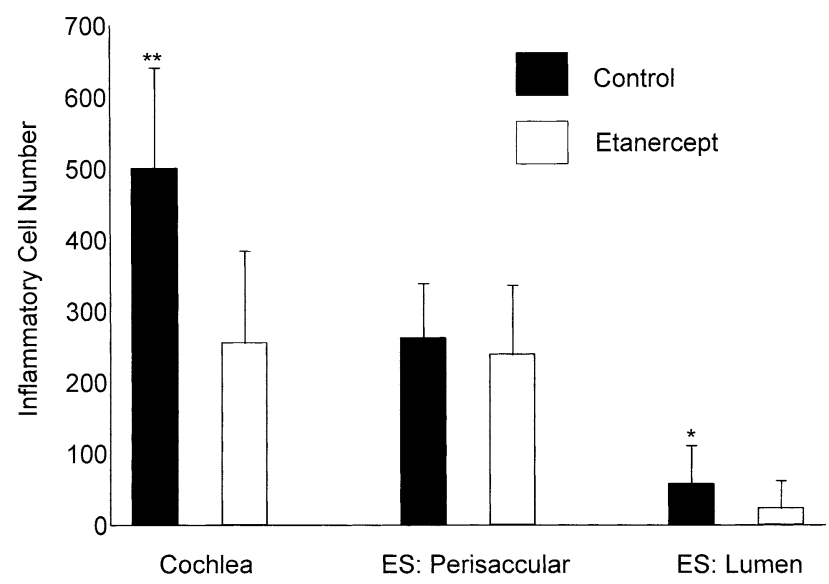

FIG. 5. The number of inflammatory cells per cochlea and endolymphatic sac section in animals with $\mathrm{KLH}$-induced labyrinthitis that did or did not receive IP injections of etanercept. Mice were sacrificed at day $7\left({ }^{* *} p<0.01 ;{ }^{*} p<0.05\right.$ Mann-Whitney, nonparametric test).

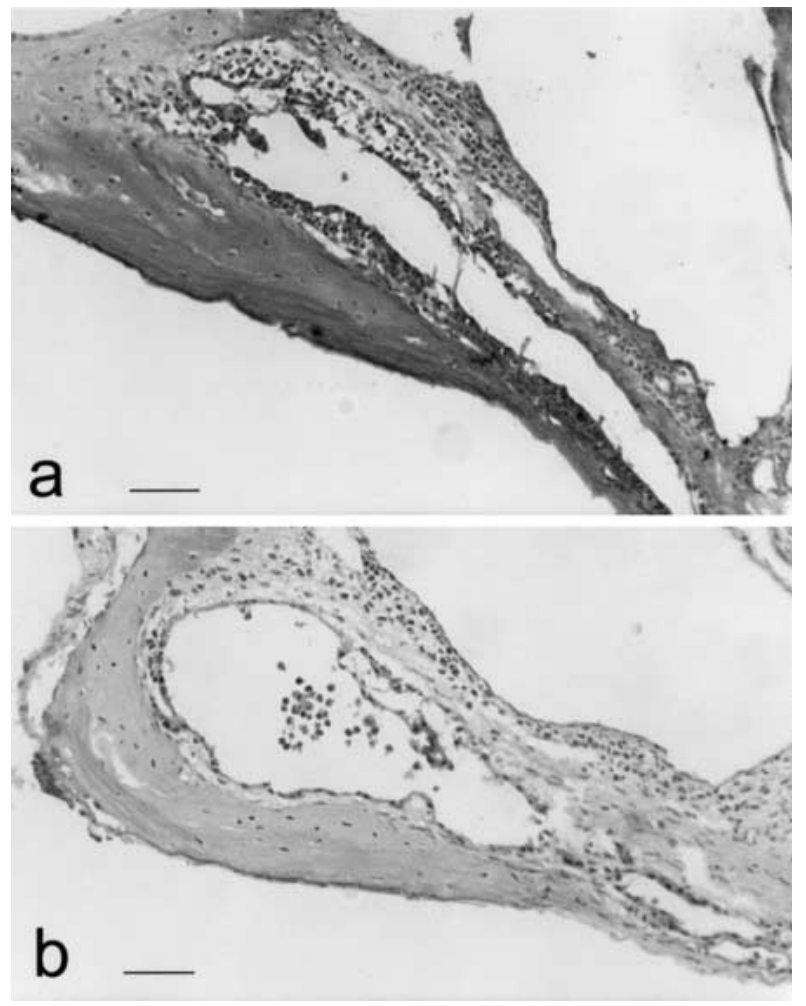

FIG. 6. Photomicrographs (brightfield) of hematoxylin and eosinstained horizontal sections of the endolymphatic sacs from animals that did (a) or did not $(\mathbf{b})$ receive etanercept. Scale bar $=100 \mu \mathrm{m}$ for $\mathbf{a}$ and $\mathbf{b}$.

The perisaccular connective tissue contains $\mathrm{T}$ cells in normal laboratory animals (Takahashi and Harris 1988a), but not in animals specially reared in germfree environments (Kawauchi et al. 1992). In the absence of any experimental manipulation, the mice used in the current study had few inflammatory cells (6/section) in this connective tissue, consistent with systemic immunocompetent cells continuously circulating through the perisaccular connective tissue providing immune surveillance. The number of these cells increases shortly after cochlear injection of either PBS or KLH (Fig. 1). We assume these cells infiltrated the tissue from the circulation. The increased number of cells suggests that the surgical and injection procedures induce an innate immune response in the perisaccular tissue. However, there is very little infiltration of cells into the cochlea in the case of PBS injection. Only a very small proportion of the perisaccular inflammatory cells after KLH injection produce proinflammatory cytokines, and the increase in the number of cells is not affected by blocking TNF $\alpha$ activity (Fig. 5), suggesting that they are not involved in signaling pathways that amplify the immune response. The speed with which the cells increase in number, the low percentage of proinflammatory cytokine-positive cells, and their appearance following cochlear trauma, independent of the presence of antigen, are consistent with the infiltration of these cells being related to the cochlea's innate immune response.

The endolymphatic sac lumen, on the other hand, responds very differently to PBS and KLH challenge of the cochlea than does the perisaccular connective tissue. There is no change in the number of cells/ section or the cytokine expression pattern following PBS injection. After KLH cochlear challenge, few inflammatory cells accumulate there until after $24 \mathrm{~h}$. This is later than the perisaccular tissue or cochlea. Most importantly, however, following KLH cochlear challenge the inflammatory cells in the endolymphatic sac lumen express the proinflammatory cytokines TNF $\alpha$ and IL-1 $\beta$ and systemic treatment of the animals with etanercept reduced the number of cells that were seen there after 7 days. The endolymphatic sac lumen, therefore, seems to participate in the adaptive immune response of the inner ear.

Antigen injected into the cochlear basal turn reaches the endolymphatic sac very quickly (Yeo et al. 1995). With this procedure it seems that antigen moves from the scala tympani to the perisaccular connective tissue with which it is connected. It is subsequently detected in or on cells that have traversed the epithelial barrier between the perisaccular tissue and the lumen (Fig. 2a, b). It is possible that, like the interdigitating dendritic cell of the lymph node, antigen-loaded phagocytic cells carry antigen into the lumen which serves as a form of secondary lymphatic tissue and where these cells can function as antigen-presenting cells. A high percentage of the lumenal cells also express proinflammatory cytokines 
that are likely to be involved in the amplification of the immune response and recruitment of cells to the cochlea. Based on these observations, it is postulated that the inflammatory cells in the lumen are instrumental in the development of the adaptive immune response in the inner ear. If antigen-presenting cells persist in the sac lumen, they may provide a mechanism whereby the cochlea could be repeatedly exposed to an immune response.

Following cochlear trauma associated with the injection of PBS or KLH, some as yet unknown signal rapidly reaches the perisaccular tissue where it causes an increased vascular permeability and an infiltration of inflammatory cells. The nature of this signal is unknown, but it is clearly independent of antigen, at least up to $12 \mathrm{~h}$, after which the number of inflammatory cells in the KLH model overtakes the PBS model. If the signal follows the same route as antigen, as seems likely, its effect is already apparent in terms of cell numbers at $3 \mathrm{~h}$, before substantial antigen has arrived. If there is antigen reaching the perisaccular tissue at about the same time or shortly after the signal is received, a second event occurs. The permeability of the lumenal epithelial cells increases and antigen either passes or is carried across into the lumen. In either case, within the lumen, antigen is localized within or on cells. In the present experiments, the antigen associated with these lumenal cells remained detectable at 7 days post-injection. A high percentage of lumenal cells also stain for IL-1 $\beta$ and $\mathrm{TNF} \alpha$, which together with the antigen localization suggests that they are functioning as activated antigen-presenting cells. The localized proinflammatory cytokine expression perpetuates and amplifies the response, attracting more cells from the circulation into the cochlea and the endolymphatic sac. Cells already present in the sac may also divide to increase the number of cells available to respond (Takahashi and Tomiyama 1995; Iwai et al. 1999). In the absence of this antigen-dependent amplification of the immune response, the antigen-independent infiltration of inflammatory cells begins to fade after $12 \mathrm{~h}$. The magnitude and preservation of the immune response in the cochlea is also critically dependent upon this amplification in and around the endolymphatic sac (Tomiyama and Harris 1986, 1987).

While the endolymphatic sac is certainly involved in the initiation of inner ear immune responses, the cochlea does have immune capability on its own. The type I fibrocytes of the spiral ligament show NF-k $\beta$ activation under several conditions (Adams 2002) and IL-1 $\beta$ expression following cochlear challenge (Satoh et al. 2002). Inflammatory cells in the cochlea express $\mathrm{TNF} \alpha$ before expression of this cytokine is significant in endolymphatic sac cells. These responses suggest that the immune reaction can be triggered in the cochlea without signals from the endolymphatic sac; however, previous data have clearly demonstrated that a functional endolymphatic sac is necessary for the full cochlear response. The difference between the endolymphatic sac and the cochlea is that constant immune surveillance by $\mathrm{T}$ cell recirculation and innate immunity affecting the cochlea seems to occur in the endolymphatic sac tissue. This accounts for the presence of immunocompetent cells in normal endolymphatic sacs (Takahashi and Harris 1988a; Kawauchi et al. 1992). Only a few inflammatory cells are seen in the normal cochlea, so recirculation may not routinely occur there.

\section{Note added in proof}

An erratum to this article appears on p. 291 in this issue.

\section{ACKNOWLEDGMENTS}

This work was supported by NIH, NIDCD DC04268, The American Otological Society, and the Medical Research Service of the U.S. Department of Veterans Affairs.

\section{REFERENCES}

ADAMS JC. Clinical implications of inflammatory cytokines in the cochlea. Otol. Neurotol. 23:316-322, 2002.

Chen M-C, Harris JP, Keithley EM. Immunohistochemical analysis of proliferating cells in a sterile labyrinthitis animal model. Laryngoscope 108:651-656, 1998.

HARRIS JP. Immunology of the inner ear: Evidence of local antigen production. Ann. Otol. Rhinol. Laryngol. 93:158-162, 1984.

Iwai H, Tomoda K, Sugiura K, Inaba M, Ikehara S, Yamashita T. T cells infiltrating from the systemic circulation proliferate in the endolymphatic sac. Ann. Otol. Rhinol. Laryngol. 108:11461150, 1999.

JuHn SK. The nature of blood labyrinth barrier in experimental conditions. Ann. Otol. Rhinol. Laryngol. 90:135-141, 1981.

KANZAKI J, OUCHI T. Steroid-responsive bilateral sensorineural hearing loss and immune complexes. Arch. Otolaryngol. 230:59, 1981 .

Kawauchi H, Ichimiya I, Kaneda N, Mogi G. Distribution of immunocompetent cells in the endolymphatic sac. Ann. Otol. Rhinol. Laryngol. 101:39-47, 1992.

Ma C-L, Billings PB, Harris JP, Keithley EM. Characterization of an experimentally induced inner ear immune response: Laryngoscope 110:451-456, 2000.

MCCABE BF. Autoimmune sensorineural hearing loss. Ann. Otol. Rhinol. Laryngol. 88:585-589, 1992.

Rask-Andersen H, Stahle J. Lymphocyte-macrophage activity in the endolymphatic sac. An ultrastructural study of the rugose endolymphatic sac in the guinea pig. ORL J. Otorhinolaryngol. Relat. Spec. 41:177-192, 1979. 
Rask-Andersen H, Stahle J. Immunodefence of the inner ear? Lymphocyte-macrophage interaction in the endolymphatic sac. Acta Otolaryngol. Stockh. 89:283-294, 1980.

Rask-Andersen H, Bagger-SJoback D, Lundquist PG. The fenestrated blood vessels of the endolymphatic sac. A freeze-fracture and transmission electron microscopic study. Am. J. Otol. 4:214-221, 1983.

SАтон H. Anti-glomerular basement membrane antibody-induced inflammation in rat cochlear plexus. Acta Otolaryngol. (Stockh.) 117:80-86, 1997.

Satoh H, Firestein GS, Billings PB, Harris JP, Keithley EM. TNF $\alpha$ as an initiator and etanercept as a potential therapeutic inhibitor of inner ear inflammation. Laryngoscope 112:1627-1634, 2002.

TAKAHASHI M, HARRIS JP. Anatomic distribution and localization of immunocompetent cells in normal mouse endolymphatic sac. Acta Otolaryngol. (Stockh.) 106:409-416, 1988a.

TAKAHASH M, Harris JP. Analysis of immunocompetent cells following inner ear immunostimulation. Laryngoscope 98:11331138, 1988b.
Takahashi M, Tомiуama S. Cell proliferation in the endolymphatic sac in situ after inner ear immunostimulation. Acta Otolaryngol. (Stockh.) 115:396-399, 1995.

TOMIYAMA S, HarRis JP. The endolymphatic sac: its importance in inner ear immune responses. Laryngoscope 96:685-691, 1986.

TomiYama S, Harris JP. The role of the endolymphatic sac in inner ear immunity. Acta Otolaryngol. (Stockh.) 103:182-188, 1987.

TOMIYAMA S, Harris JP. Elevation of inner ear antibody levels following direct antigen challenge of the endolymphatic sac. Acta Otolaryngol. (Stockh.) 107:202-209, 1989.

Wang X, Billings PB, Firestein GS, Harris JP, Keithley EM. Application of Enbrel in experimental immune-mediated sensorineural hearing loss. Assoc. Res. Otolaryngol. Abstr. 25:92, 2002.

Yeo SW, Gotteschlich S, Harris JP, Keithley EM. Antigen diffusion from the perilymphatic space of the cochlea. Laryngoscope 105:623-628, 1995.

Yimtae K, Song H, Billings P, Harris JP, Keithley EM. Connection between the inner ear and the lymphatic system. Laryngoscope 111:1631-1635, 2001. 